\title{
Ice nucleation by fertile soil dusts: relative importance of mineral and biogenic components
}

\author{
D. O’Sullivan ${ }^{1}$, B. J. Murray ${ }^{1}$, T. L. Malkin ${ }^{1}$, T. F. Whale ${ }^{1}$, N. S. Umo ${ }^{1}$, J. D. Atkinson ${ }^{1}$, H. C. Price ${ }^{1}$, K. J. Baustian ${ }^{1}$, \\ J. Browse ${ }^{1}$, and M. E. Webb ${ }^{2}$ \\ ${ }^{1}$ School of Earth and Environment, University of Leeds, Leeds, UK \\ ${ }^{2}$ School of Chemistry, University of Leeds, Leeds, UK \\ Correspondence to: B. J. Murray (b.j.murray@leeds.ac.uk)
}

Received: 10 July 2013 - Published in Atmos. Chem. Phys. Discuss.: 5 August 2013

Revised: 25 November 2013 - Accepted: 10 December 2013 - Published: 18 February 2014

\begin{abstract}
Agricultural dust emissions have been estimated to contribute around $20 \%$ to the global dust burden. In contrast to dusts from arid source regions, the ice-nucleating abilities of which have been relatively well studied, soil dusts from fertile sources often contain a substantial fraction of organic matter. Using an experimental methodology which is sensitive to a wide range of ice nucleation efficiencies, we have characterised the immersion mode ice-nucleating activities of dusts $(d<11 \mu \mathrm{m})$ extracted from fertile soils collected at four locations around England. By controlling droplet sizes, which ranged in volume from $10^{-12}$ to $10^{-6} \mathrm{~L}$ (concentration $=0.02$ to $0.1 \mathrm{wt} \%$ dust), we have been able to determine the ice nucleation behaviour of soil dust particles at temperatures ranging from $267 \mathrm{~K}\left(-6^{\circ} \mathrm{C}\right)$ down to the homogeneous limit of freezing at about $237 \mathrm{~K}\left(-36^{\circ} \mathrm{C}\right)$. At temperatures above $258 \mathrm{~K}\left(-15^{\circ} \mathrm{C}\right)$ we find that the ice-nucleating activity of soil dusts is diminished by heat treatment or digestion with hydrogen peroxide, suggesting that a major fraction of the ice nuclei stems from biogenic components in the soil. However, below $258 \mathrm{~K}$, we find that the ice active site densities tend towards those expected from the mineral components in the soils, suggesting that the inorganic fraction of soil dusts, in particular the K-feldspar fraction, becomes increasingly important in the initiation of the ice phase at lower temperatures. We conclude that dusts from agricultural activities could contribute significantly to atmospheric IN concentrations, if such dusts exhibit similar activities to those observed in the current laboratory study.
\end{abstract}

\section{Introduction}

In the absence of contaminants, water in cloud droplets remains in the supercooled state until the temperature decreases below about $237 \mathrm{~K}$ (Murray et al., 2010; Riechers et al., 2013). However, in mixed-phase clouds, particles known as ice nuclei (IN) may catalyse the transition from the supercooled to the solid state, facilitating the co-existence of liquid and ice at temperatures higher than the homogeneous freezing limit (Murray et al., 2012; Hoose and Möhler, 2012). Ice particles in a mixed-phase cloud subsequently grow as a result of the inherent difference in equilibrium vapour pressure between the two phases, which leads to the mass transfer of liquid water to ice. Also, under specific conditions, the impact of rare IN may be amplified by ice multiplication mechanisms which produce secondary ice crystals (Yano and Phillips, 2011; Crawford et al., 2012). Hence ice-nucleating particles, which tend to be rare in comparison with cloud condensation nuclei (DeMott et al., 2010; Murray et al., 2012), play a disproportionate role in cloud processes such as precipitation and radiative transfer. Consequently, characterisation of the underlying mechanisms and particles responsible for ice nucleation represents a critical step towards understanding and predicting the climatic impacts of clouds (Cantrell and Heymsfield, 2005).

Four mechanisms have been hypothesised to account for the heterogeneous nucleation of ice in mixed-phase clouds: deposition, contact, immersion and condensation, each of which has been defined by Vali (1985), although other mechanisms may also be possible (Fornea et al., 2009; Durant and Shaw, 2005). Vali (1985) defines immersion freezing as 
nucleation of a supercooled water droplet by an immersed nucleus, whereas Pruppacher and Klett (1997) arbitrarily define immersion freezing as the mode where an IN becomes immersed above $273.15 \mathrm{~K}$. Here, we adopt Vali's (1985) broader definition of immersion freezing where a particle immersed in a droplet is defined as being an immersion IN independent of how or at what temperature it got there.

The relative importance of each ice nucleation mode in the atmosphere remains uncertain (Cantrell and Heymsfield, 2005). However, a number of field and modelling studies have indicated that in mixed-phase clouds water saturation is a prerequisite for the formation of ice, suggesting that deposition mode nucleation or condensation below water saturation may be of limited importance for such clouds (Field et al., 2012; Twohy et al., 2010; Ansmann et al., 2009; de Boer et al., 2011; Westbrook and Illingworth, 2011). Consequently both immersion and contact modes are expected to dominate ice formation in mixed-phase clouds (Hoose et al., 2010b). The relative importance of contact mode nucleation remains unclear (e.g. Hoose et al., 2010b; Philips et al., 2007).

The composition, distribution and relative efficiencies (as quantifiable, for example, by the determination of nucleation rates or ice active site densities) of ice-nucleating particles have become topics of intense research (DeMott et al., 2011; Murray et al., 2012; Hoose and Möhler, 2012). Ice nuclei which are thought to be of potential importance include species such as soot, volcanic ash, mineral dusts and biological particles such as bacteria, fungal spores and pollen grains. Laboratory studies indicate that inorganic ice nuclei tend to exhibit significant activity only at temperatures below $\sim 258 \mathrm{~K}\left(-15^{\circ} \mathrm{C}\right)$ (Hoose and Möhler, 2012; Murray et al., 2012). Conversely, while biological IN such as intact bacteria or pollen grains are amongst the most efficient nucleators known, their atmospheric abundance is typically orders of magnitude lower than that of mineral dusts or soot in the atmosphere (Després et al., 2012; Murray et al., 2012; Hoose et al., 2010b). This has resulted in questions as to whether they are relevant in ice formation processes in mixed-phase clouds, at least on a global scale (Hoose et al., 2010a; Murray et al., 2012; Burrows et al., 2013). However, on regional scales both observations and model studies have shown that biological particles may indeed play significant roles in atmospheric ice formation processes (e.g. Phillips et al., 2009; Prenni et al., 2009).

The importance of mineral dust particles in mixed-phase cloud glaciation has been demonstrated both in field (Sassen et al., 2003; Pratt et al., 2009; Choi et al., 2010; Ansmann et al., 2008; Creamean et al., 2013) and modelling (Hoose et al., 2010b; Lohmann and Diehl, 2006; Atkinson et al., 2013) studies. In the case of model simulations, dusts have been treated as being purely composed of mineral components, which is not unreasonable given that the major dust sources are located in arid regions (Prospero et al., 2002; Ginoux et al., 2012). However, a number of recent field studies have shown that significant quantities of biological materi- als may be co-transported from sources together with mineral dusts (Pratt et al., 2009; Hallar et al., 2011; Creamean et al., 2013). For instance, during their study of ice crystal residues sampled from a wave cloud above Wyoming, Pratt and co-workers employed aerosol time-of-flight mass spectrometry to show the most abundant particle type found was mineral dust, of which $60 \pm 13 \%$ was internally mixed with biological and/or humic materials. Using a combination of techniques, the authors showed that the most likely source of the particles influencing the cloud was from long-range transported dust which was lofted from Central China or Eastern Mongolia. Since organic species can be internally mixed with mineral particles in dust aerosols, in the current manuscript we use the phrase "mineral dust" to refer to any dust which can be mobilized from soils, and may or may not contain organic matter.

To date, the impact of agricultural soil dusts on atmospheric ice formation remains poorly constrained, despite the fact that soil organic matter (SOM) has long been proposed as a source of potent IN (Vali, 1968; Schnell and Vali, 1972). Land use such as agriculture can result in anthropogenic dust emissions, both through direct injection of dust particles during tillage, and through loss of soil cohesion leading to increased erosion rates (Zender et al., 2004). On a global scale, dusts emanating from agricultural sources are thought to represent a major contribution to anthropogenic dust emissions (Tegen et al., 2004). The "best-guess" estimates of the last IPCC report (Forster et al., 2007) suggested a contribution from anthropogenic emissions of between 0 and $20 \%$ to the total atmospheric dust burden. More recently, Ginoux and co-workers presented global high-resolution mapping of dust sources, using estimates of dust optical densities derived from satellite-based measurements with the Moderate Resolution Imaging Spectrometer together with land use data sets (Ginoux et al., 2012). Dust sources were attributed to natural and anthropogenic (primarily agricultural) origins, which accounted for $75 \%$ and $25 \%$ of emissions respectively.

Fertile soil is a complex mixture of both inorganic and organic matter, the latter being composed of plant litter, ani$\mathrm{mal} / \mathrm{microbial}$ residues, lipids, carbohydrates, peptides, cellulose, lignin and humic substances such as humic and fulvic acids (Simoneit et al., 2004; Oades, 1993). Sub-10 $\mu$ m dusts sampled at agricultural sites contain significant amounts of organic carbon (OC) (Baker et al., 2005; Chow et al., 2003). In a recent study, Conen et al. (2011) demonstrated that organic matter present in non-desert soils, which tend to have a higher OC content than soils from desert regions, can lead to ice-nucleating activities up to one thousand times greater than those of the mineral components in the soil on a per-mass basis. Although OC in soils can coat substantial fractions of the underlying mineral surfaces (Mayer, 1994), the impacts of this upon the overall ice-nucleating ability across temperatures relevant for ice formation in mixedphase clouds remains unclear. 
Table 1. Soil sample information. Location, mean annual (air) temperature (MAT), specific surface area as estimated by laser diffraction (SSA), K-feldspar content in the dust fraction and bulk organic carbon content of the soils examined during this study. Mean annual air temperatures are calculated from $5 \mathrm{~km} \times 5 \mathrm{~km}$ grid cells of UK Climate Projections (UKCP09) observation data sets provided by the UK Met Office.

\begin{tabular}{|c|c|c|c|c|c|c|c|}
\hline \multirow[b]{2}{*}{ Sample } & \multirow[b]{2}{*}{ Coordinates } & \multirow[b]{2}{*}{$\begin{array}{r}\text { MAT } \\
\left({ }^{\circ} \mathrm{C}\right)\end{array}$} & \multicolumn{3}{|c|}{$\operatorname{SSA}\left(\mathrm{m}^{2} \mathrm{~g}^{-1}\right)^{*}$} & \multirow{2}{*}{$\begin{array}{r}\% \text { K-feldspar } \\
(\% \text { mass } \\
<11 \mu \mathrm{m})\end{array}$} & \multirow{2}{*}{$\begin{array}{r}\% \text { OC } \\
(\% \text { mass, } \\
\text { bulk) }\end{array}$} \\
\hline & & & Used & $\begin{array}{l}\text { Upper } \\
\text { Limit }\end{array}$ & $\begin{array}{c}\text { Lower } \\
\text { Limit }\end{array}$ & & \\
\hline A & $51.68925,-1.69669$ & 10.7 & 1.47 & 2.69 & 0.77 & 9.8 & 12.7 \\
\hline B & $52.62055,-1.2933$ & 9.7 & 0.74 & 1.34 & 0.46 & 11.0 & 2.9 \\
\hline $\mathrm{C}$ & $53.52474,-1.64263$ & 8.9 & 1.86 & 3.23 & 1.17 & 2.1 & 2.1 \\
\hline $\mathrm{D}$ & $52.62035,-1.39551$ & 10.1 & 2.31 & 4.11 & 1.60 & 8.2 & 2.5 \\
\hline
\end{tabular}

* For the specific surface areas, the values used for the determination of ice active site densities were taken using a refractive index of $1.53+0.03 i$. The upper and lower limits are taken from the maximum and minimum SSAs calculated when $n_{\mathrm{i}}$ is allowed to vary between $0.1-0.01$, and are used together with the uncertainties in size binning of droplets for the calculation of error bars in $n_{\mathrm{S}}$ values (see Sect. 2.4).

In the following work, we examine the relative contribution of organic and mineral components to the icenucleating ability of dusts (filtered to $<11 \mu \mathrm{m}$ ) from soil samples collected in England. Using a combination of experimental methodologies, the characteristic ice nucleation behaviour of the samples is assessed over a wide range of temperatures relevant for mixed-phase tropospheric clouds $(268>T>237 \mathrm{~K})$. The freezing activities are examined using the time-independent (singular) model of ice nucleation and we assess the relative importance of the mineral and the biogenic ice nuclei in these samples.

\section{Experimental}

\subsection{Soil collection and dust extraction}

Soil samples with contrasting mineralogies were collected from within the top $10 \mathrm{~cm}$ of the surface at four sites around England (Table 1). Sample A was collected from near a hedgerow in soil which had not recently been ploughed and contained a large proportion of OC (12.7 wt\%) in varying stages of decomposition. In contrast, samples B-D were collected from arable agricultural fields which were regularly ploughed. These samples contained between 2.1 and $2.9 \mathrm{wt} \%$ organic carbon.

In order to focus our ice nucleation study on a size fraction which could potentially become aerosolised in natural soil samples, it was necessary to sieve and filter the samples. First, the samples were air-dried and sieved to $<2 \mathrm{~mm}$. These samples were further dry-sieved to remove particulates larger than $63 \mu \mathrm{m}$, then suspended in water in order to wet-sieve them through a $45 \mu \mathrm{m}$ sieve. $45 \mathrm{~mL}$ aliquots of the resulting suspension were poured into polypropylene tubes (to a height of $8 \mathrm{~cm}$ ), shaken and allowed to settle for $60 \mathrm{~s}$ in order to preferentially remove larger particles prior to the subsequent filtration. The supernatant was withdrawn from the top $4 \mathrm{~cm}$ and subsequently vacuum filtered through an $11 \mu \mathrm{m}$

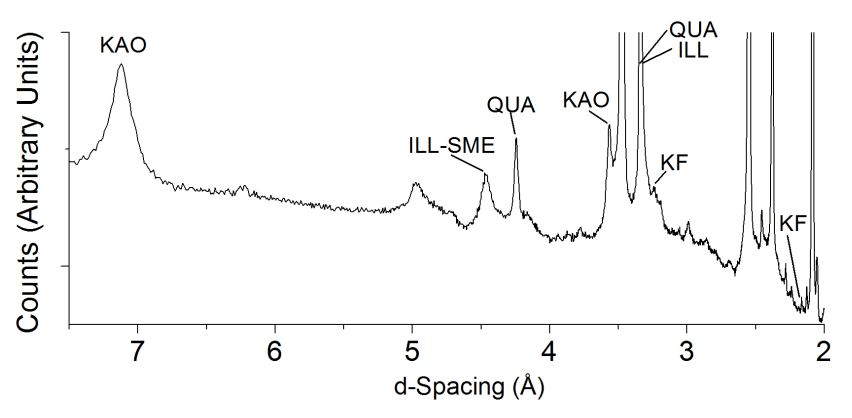

Fig. 1. Sample X-Ray diffraction pattern showing assignments of major mineral components in soil D. Assigned are a selection of the peaks associated with the major components found in the soil dusts. Labelled are peaks for KAO - Kaolinite, ILL-SME - IlliteSmectite, QUA - Quartz, ILL - Illite, KF - Potassium Feldspar. Note that assignments shown in the figure are not exhaustive; extensive information on peak positions can be found in Hillier (1999, 2000).

nylon mesh filter (Millipore, NY1104700). Possible consequences of the above treatments for the resulting particles sampled include a redistribution of dissolved organic carbon across these particles due to the wet sieving process, as previously highlighted by Conen et al. (2011). In addition, the act of sieving/filtration through a nylon net filter as a method of particle selection could result in changes to the distribution of particle shapes at a given size, as whether elongated particles make it through the square openings is dependent on particle orientation. The resulting filtrate was dried at slightly above ambient temperatures in an oven at $313 \mathrm{~K}$. A known mass of this dry dust was then resuspended in a known mass of water to create a suspension for ice nucleation experiments (Sect. 2.3).

\subsection{Characterisation}

The mineralogical composition of the soil dust fraction $(<11 \mu \mathrm{m}$, see Table 2$)$ was obtained by X-ray diffraction 
(XRD) analysis. A sample XRD diffraction pattern indicating the major peaks used during the assignment of the mineral components is indicated in Fig. 1. Due to the small quantity of the sample, the standard spray-dry method (Hillier, 1999; Broadley et al., 2012) was unsuitable and a different approach was taken. The soil dust fraction was doped with a known mass of corundum as internal standard and then packed into the sample holder of the X-ray diffractometer. Reference intensity ratios for individual minerals to the standard were determined using reference samples of minerals with known composition. Accordingly, the concentrations of each mineral component in the soil dust samples could be determined. The relative intensities for 2-4 peaks of each mineral in the soil dusts were measured and used to establish the relative proportions of each mineral listed in Table 2. Furthermore, the use of multiple peaks helped to ensure that there was no preferred orientation in the sample. This methodology and the spray-dry method have been compared using other mineral dust samples, such as NX-illite and Arizona Test Dust, in order to validate this approach. The results from the two techniques were indistinguishable from one another.

The percentage organic carbon in the bulk soil samples (sieved to $<2 \mathrm{~mm}$ ) was determined by dry combustion using a Thermo Flash EA1112 elemental analyser. In order to remove inorganic carbon (i.e. carbonates) from the soils prior to analysis for organic carbon, samples were treated with $6 \%$ sulfurous acid (Skjemstad and Baldock, 2007). See Table 1 for results.

For calculation of ice active site densities (Sect. 2.4) we have estimated the specific surface areas (SSA) of suspended soil mineral particles from the particle size distribution (Fig. 2). The size distribution was determined using a Malvern Mastersizer 2000E laser diffraction instrument. This instrument measures the angular intensity of scattered light from a laser $(\lambda=633 \mathrm{~nm})$, and then predicts the particle size distribution, in terms of volume equivalent spheres, using Mie Theory. The size range measurable by the Mastersizer $2000 \mathrm{E}$ is quoted as $0.1-1000 \mu \mathrm{m}$, depending on the sample. However, owing to the principles of operation, techniques based on laser diffraction tend to be biased towards larger particles in the sample (Storey and Ymen, 2011). We have used the manufacturers standard analysis model for samples containing irregular particles in order to determine volume equivalent spherical diameters. Values for the refractive index (both the real, $n_{\mathrm{r}}$, and imaginary, $n_{\mathrm{i}}$, components) are required input parameters for the analysis, with the output size distribution particularly sensitive to $n_{\mathrm{i}}$ (Sperazza et al., 2004). For $n_{\mathrm{r}}$ a value of 1.53 was chosen in line with Eshel et al. (2004) and Pieri et al. (2006). If they are unknown, optimal values of $n_{\mathrm{i}}$ are selected by minimisation of the residual difference between the measured diffraction pattern and that modelled by Mie theory, as recommended by the manufacturer. For $n_{\mathrm{i}}$, values between $0.1-0.01$ have been suggested for soil samples (Özer et al., 2010). We found that the residuals tended to be lowest at around $n_{\mathrm{i}}=0.03$, and this value

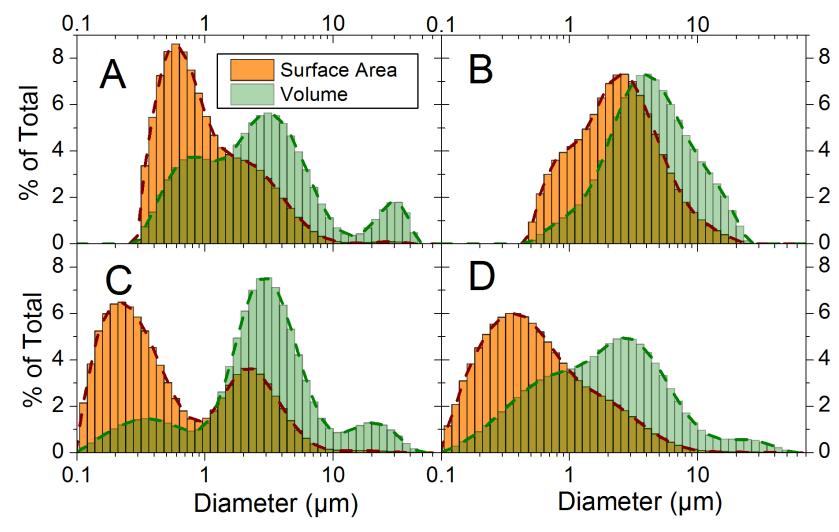

Fig. 2. Particle size distribution histograms determined by laser diffraction for soil dusts A-D examined during this study. Dashed lines following the surface area and volume distributions are provided for clarity.

was used to estimate the SSA. The maximum and minimum values of the SSA arising from $n_{\mathrm{i}}$ values within this range (0.1-0.01) were used to estimate the uncertainty in the SSA (see Table 1) for use in the calculation of ice active site densities (Sect. 2.4).

It should be noted that in expressing the particle size distribution in volume equivalent sphere diameters, for real samples deviations in the calculated amount of surface area available to nucleate ice may occur. Particles can be nonspherical, porous and have surface roughness. Typical values of particle sphericity (i.e. the ratio of the surface area of a sphere with the same volume as the given particle to the actual surface area of the particle) can approach unity for rounded grains or cubic particles such as calcite, while highly irregular particles such as clays or mica can have sphericities as low as 0.2 (Yang, 2003; Holdich, 2002). As noted by Murray et al. (2012), for comparison of ice active site density data between studies the data treatment between the studies needs to be considered (Sect. 2.4).

In the particle size analysis of soils, removal of organic matter has been recommended prior to soil particle size analysis due to the fact that organic matter facilitates aggregation (McGee and Bauder, 1986; Pansu and Gautheyrou, 2006). Consequently, organic matter was removed from the samples by oxidation with $35 \%$ hydrogen peroxide at $323 \mathrm{~K}$. In the case of soils containing calcite (soils A, B and D), which also facilitates aggregation and interferes with the oxidation of SOM by hydrogen peroxide, the carbonate was first removed using $1 \mathrm{M}$ sodium acetate at $\mathrm{pH} 5$ (Pansu and Gautheyrou, 2006). Following the pre-treatments, the soil dusts were chemically dispersed in an aqueous solution containing $0.595 \%(w: v)$ sodium hexametaphosphate and $0.132 \%$ $(w: v)$ sodium carbonate (Oorts et al., 2005). Hence, the surface areas derived from laser scattering which we quote are for the non-aggregated inorganic component (excluding the calcite) of the soil. 
Table 2. Mineralogies of the soil dusts $(<11 \mu \mathrm{m})$ determined by X-ray diffraction (XRD). Listed in weight percent are: CA - calcite, QU quartz, NF - Na-feldspar, KF - K-feldspar, ILL - illite, ILL-SM - illite-smectite, KAO - kaolinite, OM - other minerals: the sum of the rarer minerals in the samples, and OU - others unidentified: material which was not resolved using XRD.

\begin{tabular}{lrrrrrrrrr}
\hline Sample & CA & QU & NF & KF & ILL & ILL-SM & KAO & OM & OU \\
\hline A & 0.4 & 13.5 & 1.7 & 9.8 & 21.7 & 10.7 & 19.5 & 5.3 & 17.4 \\
B & 6.7 & 19.8 & 2.1 & 11.0 & 7.6 & 17.9 & 6.3 & 9.0 & 19.6 \\
C & 0.0 & 10.0 & 1.0 & 2.1 & 6.8 & 20.7 & 55.9 & 0.0 & 3.5 \\
D & 1.0 & 12.6 & 3.2 & 8.2 & 20.4 & 11.9 & 20.0 & 3.3 & 19.4 \\
\hline
\end{tabular}

\subsection{Drop freezing experiments}

To assess the freezing behaviour of soil dusts over a wide temperature range, three separate sets of droplet freezing experiments were performed, each with different droplet sizes, ranging in volume from $10^{-12}$ to $10^{-6} \mathrm{~L}$ (diameter $=8 \mu \mathrm{m}$ $1.45 \mathrm{~mm}$ ). A given droplet freezes at a temperature where a particular active site triggers freezing. Smaller droplets, containing less surface area of soil, will on average contain a smaller sample of active sites. Owing to the lower probability that these smaller droplets will contain rarer, more efficient active sites, these droplets will tend to freeze at lower temperatures. Conversely, larger droplets, containing more surface area, will tend to freeze at higher temperatures because they will contain a broader spectrum of nucleation sites including rarer sites which are capable of triggering ice formation at warmer temperatures.

The three sets of droplet freezing experiments employed pico-, nano- and microlitre volume droplets (Fig. 3). In the case of the pico- and nano-litre drop freeze experiments, a modified experimental apparatus was used to probe ice nucleation as was previously used for published picolitre droplet experiments (Murray et al., 2010, 2011; Broadley et al., 2012; Atkinson et al., 2013). Briefly, droplets were deposited onto siliconized glass slides (Hampton Research, HR3-278T) by nebulisation of soil dust suspensions. The suspension concentration used during nanolitre drop freezing experiments (nano-DFE) ranged from $0.015-0.1 \mathrm{wt} \%$. To prevent mass transfer during cooling, the droplets were encased in silicone oil. The temperature of the droplets was manipulated using a custom-built aluminium cold stage, the temperature being varied using a flow of liquid nitrogen balanced by cartridge heaters controlled by a Eurotherm 2416 microprocessor controller. Using this setup, the uncertainty in temperature measurement was $\pm 0.4 \mathrm{~K}$. A cooling rate of $10 \mathrm{~K} \mathrm{~min}^{-1}$ was employed for experiments. A small aperture in the cooling stage allowed for droplet illumination in the transmission mode: the gap between the cooling stage and the glass slide was bridged using a thin slide of diamond with a high thermal conductivity (Element 6, 145-500-0291). Droplet freezing was monitored using an Olympus BX-51 microscope coupled to a digital camera $(3.33 \times$ magnification).
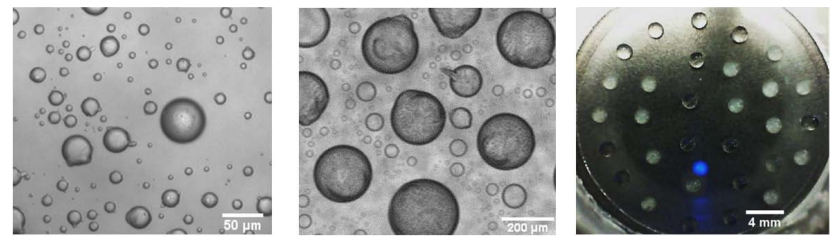

Fig. 3. Droplet sizes used to examine the ice-nucleating efficiencies of soil dusts. From left to right are images captured during the pico-, nano- and micro- drop freezing experiments (DFE) respectively.

In order to extend the range of experimentally observable ice nucleation events to lower temperatures, freezing was also examined in picolitre droplets (pico-DFE) created from nebulisation of a suspension containing $0.1 \mathrm{wt} \%$ soil dust. The only modification to the above experimental setup was the use of different optics (objective and camera mount) to provide $10 \times$ magnification. In contrast to the nano- and micro-DFEs, in the pico-DFE the size of the droplets examined in the experiment (total range $=10-22 \mu \mathrm{m}$ ) is so small that they do not each contain a representative distribution of dust particles. Accordingly, we do not attempt to quantify the nucleation efficiencies of soil particles normalised to surface area of nucleant per droplet in the case of the pico-DFEs. Instead, the data are presented using the cumulative nucleation spectrum in Sect. 3.2 (nucleation events per unit volume of liquid, see Sect. 2.4), which allows us to establish the influence of heat treatment on a sample's ice-nucleating ability.

The micro-DFE has been tested and validated previously (Atkinson et al., 2013), and is only briefly discussed here. $1.0 \pm 0.1 \mu \mathrm{L}$ droplets of soil dust suspensions were dispensed using a Picus Picolitre Biohit digital pipette onto a $22 \mathrm{~mm}$ diameter siliconised glass slide (Hampton Research, HR3-231), which was cooled from the underside using an Grant-Asymptote EF600 Stirling engine. On cooling, freezing events in droplets were recorded using a digital camera. The ice-nucleating activities of two humic substances purchased from the International Humic Substances Society, Leonardite humic acid and Suwanhee River fulvic acid (SRFA), were also examined using this technique. This was performed in order to compare the activities of these proxies for naturally occurring humic-like substances (HULIS) with those of the soil dusts. 
During studies of environmentally sampled ice nuclei of initially unknown composition, sensitivity to heat treatment has become a commonly employed technique to aid in classification of IN as biogenic or otherwise (Christner et al., 2008a, b; Henderson-Begg et al., 2009; Garcia et al., 2012). This straightforward test operates on the principle that known proteinaceous IN from intact bacteria and fungi are progressively lost upon heating to $363 \mathrm{~K}$ (Pouleur et al., 1992). To test the effects of heat on the ice nucleation activity of the soils, the suspensions were heated to $363 \mathrm{~K}$ for $10 \mathrm{~min}$ and allowed to cool to room temperature.

Thermally stable organic carbonaceous components have also previously been shown to represent an active icenucleating component in soil dusts (Conen et al., 2011). In order to test for these heat-stable carbonaceous ice nuclei the carbonaceous fraction was removed through digestion with hydrogen peroxide. For this purpose, dry filtered soil dust was suspended in a $35 \%$ solution of the peroxide and heated to $323 \mathrm{~K}$ for $30 \mathrm{~min}$. Final solutions were diluted by a factor of 100 before examining the ice-nucleating activities to minimize the concentration of the peroxide in the solution. When similar treatment was applied to K-feldspar, which was used as a reference for the ice-nucleating activities of mineral dusts during this study, no detectable changes to the ice-nucleating activities were observed.

During preliminary work it was noted that haloes of condensate formed around freezing droplets and that these haloes could sometimes trigger freezing in neighbouring droplets, artificially enhancing the probability of freezing. The phenomena of condensate halos around freezing microlitre-sized droplets was recently discussed in some detail by Jung et al. (2012). This is caused by a latent-heatdriven release of water vapour during the freezing process that subsequently condenses as a liquid onto the substrate, which then freezes outwards from the frozen or freezing droplet. To minimize the impact of these condensate haloes the atmosphere above the droplets was purged with a flow of dry nitrogen gas at a rate of $180 \mathrm{~cm}^{3} \mathrm{~min}^{-1}$. The droplets were spaced a minimum of $0.75 \mathrm{~mm}$ apart, which eliminated the problem of condensate haloes nucleating nearby droplets.

\subsection{Data evaluation}

The starting point for our analysis of the ice-nucleating efficiencies of the soil dusts is the singular approximation of heterogeneous ice nucleation, which, in contrast to a stochastic nucleation rate approach, assumes that nucleation behaves as a time-independent process. In the singular approximation, nuclei of differing efficiencies are distributed among aqueous droplets and the resulting differences in freezing temperature between droplets is a much stronger effect than differences associated with the stochastic, time-dependent nature of nucleation (Vali, 2008). Hence, the pragmatic singular approximation is commonly used (Murray et al., 2012; Hoose and Möhler, 2012; Connolly et al., 2009), although it should also be noted that there may be situations in nature and in the lab where the time-dependent behaviour of nucleation becomes important (Westbrook and Illingworth, 2013; Niedermeier et al., 2011; Welti et al., 2012; Murray et al., 2011).

According to the singular approximation, for droplets of volume $V$, the cumulative fraction frozen by a particular temperature, $F(T)$, can be related to a cumulative number of active ice-nucleating sites within each droplet, $K(T)$, by Vali (1971):

$F(T)=1-e^{(-K(T) V)}$.

Rather than expressing the cumulative number of active sites as a function of droplet volume, this quantity can be normalised to the mass $m$ of nucleant present within the droplets via (Vali, 1995; Murray et al., 2012):

$F(T)=1-e^{\left(-n_{\mathrm{m}}(T) m\right)}$,

where $n_{\mathrm{m}}(T)$ is the ice active site density per unit mass. However, for cases where the surface area of the nucleating particles is readily definable, the number of active sites may be expected to scale directly with surface area (Niemand et al., 2012; Murray et al., 2011; Niedermeier et al., 2010; Augustin et al., 2013; Hartmann et al., 2013). Consequently, comparison of active site densities per unit mass is contingent upon the specific surface areas across the samples being similar. Such issues can be avoided by expressing the cumulative ice active site density in terms of the nucleant surface area per droplet, $\sigma$ (Murray et al., 2011; Connolly et al., 2009; DeMott, 1995):

$F(T)=1-e^{\left(-n_{\mathrm{s}}(T) \sigma\right)}$,

where $n_{\mathrm{s}}(T)$ is the cumulative ice active surface site density, or simply the ice active site density. In calculating the fraction of droplets frozen using the nano-DFE setup, droplets were placed into three size bins in order to constrain the surface area per drop to a narrow range, which is necessary to reduce uncertainties in $\sigma$, and hence uncertainties in ice active site densities. In microlitre experiments this size binning was not necessary as the droplet population is monodisperse $(1.0 \pm 0.1 \mu \mathrm{L})$. In nanolitre experiments, bin centres were estimated from the median of the droplet sizes enclosed within each bin; bin centres used ranged from 0.1-6nL. Size binning into three bins was also performed for experiments using picolitre-sized droplets, with bin centres ranging from $0.25-1.70 \mathrm{pL}$. With three bins we were able maximise the number of droplets per bin (average per bin $=17$ in nanolitre experiments, 45 in picolitre experiments) while minimising the errors in droplet volume. The droplet size distribution is typically skewed towards smaller sizes, hence we estimate the bin centre with a median volume rather than a mean. Confidence limits are established in the range of droplet volumes enclosed in each bin, within which limits $68 \%$ of the droplets fall (which, were the droplet sizes distributed normally, would correspond to \pm 1 standard deviation). The largest uncertainty produced by the finite bin width 


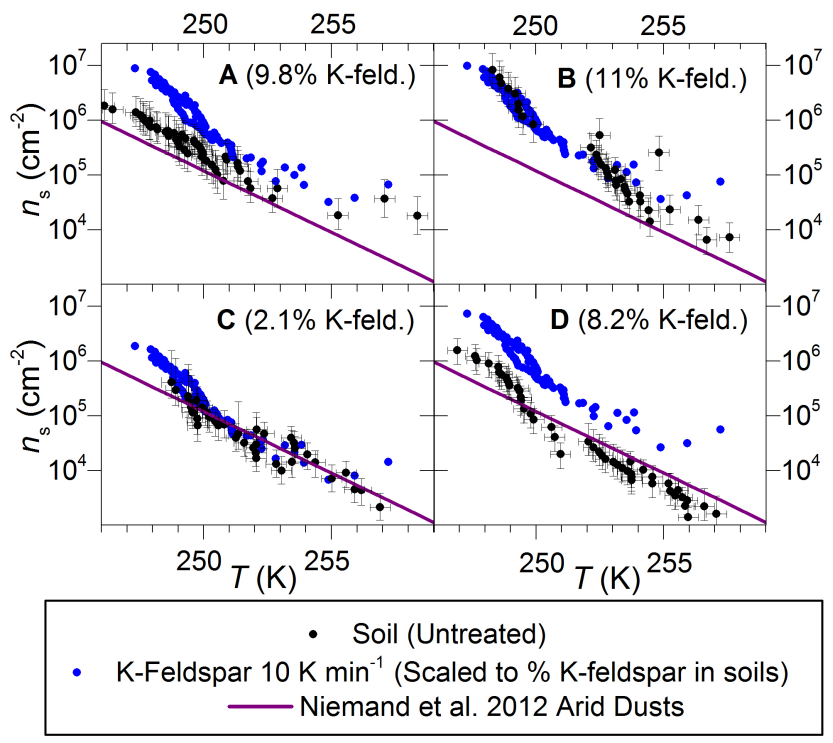

Fig. 4. Ice active site densities $\left(n_{\mathrm{S}}\right)$ values determined from nanolitre drop freezing experiments for soils A-D. Each graph shows the data selected from at least 2 droplet size bins, as outlined in Sect. 2.4. The feldspar data are for K-feldspar at the same cooling rates $\left(\mathrm{d} T / \mathrm{d} t=-10 \mathrm{~K} \mathrm{~min}^{-1}\right)$ as used for the soils. The $\mathrm{K}$-feldspar $n_{\mathrm{S}}$ has been scaled down according to the feldspar mass fraction in each of the soils (see Sect. 3.1). Also shown is the parameterisation for arid dusts, as provided by Niemand et al. (2012).

is less than $\pm 87 \%$ of the bin median droplet volume for all nanolitre experiments and less than $\pm 53 \%$ for all picolitre experiments. As noted in Sect. 2.3, the actual amount of nucleant per droplet in picolitre experiments is expected to be a probabilistic function of the droplet volume. Accordingly, for the comparison of activities between the heat-treated and non heat-treated soil samples, exactly the same size bins were chosen to analyse both heated and non-heated samples. Uncertainties resulting from the finite range of drop sizes within each bin were combined with the uncertainties in the measured mineral specific surface area (Sect. 2.2) during calculation of $\sigma$ within each bin. Uncertainties in $\sigma$ are propagated into calculation of ice active site densities, and are expressed as error bars in Figs. 4 and 6.

\section{Results}

\subsection{Nanolitre droplet freezing experiments}

The ice active site densities as calculated using Eq. (3) for nanolitre-sized droplets are shown in Fig. 4. Despite the differences in organic content and mineralogy the four soils exhibit similar $n_{\mathrm{s}}$ values. They range from $\sim 10^{3}-10^{4} \mathrm{~cm}^{-2}$ at $257 \mathrm{~K}$ to $\sim 10^{6}-10^{7} \mathrm{~cm}^{-2}$ at $248 \mathrm{~K}$.

For comparison, we also show the parameterisation of $n_{\mathrm{S}}$ values for arid region mineral dusts presented by Niemand et al. (2012) as well as data for K-feldspar using the same experimental procedure as used for the soils. Recently, K-feldspar (microcline) has been shown to be a major ice-nucleating component in mineral dusts (Atkinson et al., 2013). The K-feldspar $n_{\mathrm{s}}$ data in Fig. 4 have been scaled down to the feldspar content in each of the soils $(\leq 11 \%$, see Table 1) for the purpose of comparison. In the absence of a mineral-resolved size distribution for our soils we make the approximation that the K-feldspar mass fraction in the soils can be used to estimate the available surface area of this mineral able to nucleate ice (i.e. $w t \% \mathrm{~K}$-feldspar $=\%$ of total SSA attributable to K-feldspar in the samples). It is important to note that, in this feldspar scaling approximation, it is assumed that the K-feldspar component of the soils has a similar size distribution as that measured for the bulk soils here and also that the feldspar in soils has not been chemically altered in a way which would change its ice-nucleating ability. Inspection of Fig. 4 shows that, despite these assumptions, the feldspar scaling approximation is a first-order predictor of the ice-nucleating ability of these soil samples in this temperature range, predicting $n_{\mathrm{s}}$ to within an order of magnitude.

If there were a significant number of biogenic IN active in the soils in this temperature range then we would anticipate the soil dusts to have $n_{\mathrm{s}}$ values in excess of those for the feldspar or arid region mineral dusts. The absence of an enhancement suggests that the ice-nucleating activity in this temperature regime is dominated by the mineral components rather than the organic matter in the soils.

\subsection{Picolitre droplet freezing experiments}

The results from droplet freezing experiments with picolitresized droplets containing unheated and heated soil samples are shown in Fig. 5. In these experiments each droplet did not contain a representative distribution of particles since the mass per droplet was so small $(<2$ pg per drop). In this regime we estimate that most droplets do not contain particles with diameters above $0.4 \mu \mathrm{m}$ despite these particles making up a significant part of the distribution. Hence, as noted in Sect. 2.3, we were unable to determine $n_{\mathrm{m}}$ or $n_{\mathrm{s}}$ from these freezing data. Nevertheless, the comparison of heated and non-heated samples provides information on the nature of the IN that are active at temperatures $<249 \mathrm{~K}$. Since the concentration of dust in the heated and non-heated experiments was held constant, we can plot $K(T)$, which is the number of active sites per unit volume of suspension (Murray et al., 2012; Vali, 1971). Using this relative measure of ice-nucleating activity, we can see that the ice nuclei in these samples exhibit stability towards heat treatment at $363 \mathrm{~K}$. The picolitre experiments suggest that the IN population in these soil samples is dominated by inorganic IN below $249 \mathrm{~K}$. 


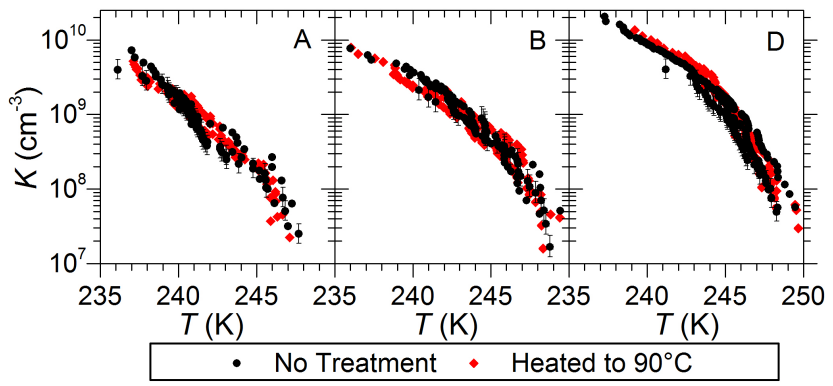

Fig. 5. Cumulative nucleus spectrum for soil dusts A, B and D in the $<11 \mu \mathrm{m}$ fraction determined from the pico-DFE. For clarity, error bars are only shown for one size bin in each graph. The uncertainty in temperature measurement was $\pm 0.4 \mathrm{~K}$. Data for sample $\mathrm{C}$ were not obtainable, owing to insufficient soil dust to perform the experiment.

\subsection{Microlitre droplet freezing experiments}

To extend our measurements to warmer temperatures, the freezing behaviour of the dusts was further probed using microlitre-sized droplets, with individual soil dust concentrations in the range of $0.04-0.1 \mathrm{wt} \%$ and a cooling rate of $1 \mathrm{~K} \mathrm{~min}^{-1}$. The resulting $n_{\mathrm{s}}$ values for the soil dusts determined using microlitre droplets are illustrated in Fig. 6.

Also shown in Fig. 6 are the $n_{\mathrm{s}}$ values expected on the basis of the inorganic mineral content of the soils in this regime using the mass fraction of K-feldspar in each sample. The recent parameterisation from Atkinson et al. (2013), who also used a cooling rate of $1 \mathrm{~K} \mathrm{~min}^{-1}$, was used in this plot. In order to compare with this parameterisation for $n_{\mathrm{s}}$, which was derived using surface areas from gas adsorption isotherms, the parameterisation was rescaled according to the surface area derived from laser diffraction for the same sample. The surface area estimated from laser diffraction for the feldspar sample that Atkinson et al. (2013) used was 3.5 times smaller than that derived from the gas adsorption technique and consequently the $n_{\mathrm{s}}$ values are 3.5 times larger. The discrepancy can be ascribed to two key factors: firstly, the particles are aspherical and irregular which will enhance their surface area over that of an equivalent sphere (the fundamental quantity measured in laser diffraction is the volume equivalent sphere diameter). Secondly, the laser diffraction technique is insensitive to the smallest particles in the distribution; hence the estimated specific surface area will be smaller than that from a gas adsorption technique. The issue of comparing $n_{\mathrm{s}}$ values derived from different methods of establishing surface area is also discussed in two recent review articles (Hoose and Möhler, 2012; Murray et al., 2012).

In contrast to experiments examining activities at lower temperatures, in microlitre experiments, enhancement of the ice active site densities over the expected nucleation activity from the K-feldspar component was observed (Fig. 6). A potential reason for this contrasting behaviour may be the occurrence of rare, but highly active, ice nuclei with abundances only detectable in microlitre drop freeze assays. One possibility is that the SOM enhances the ice-nucleating ability of these soil dusts at warmer temperatures $(T>258 \mathrm{~K})$. In order to test this hypothesis the soil dusts were heat treated and digested with hydrogen peroxide in order to establish whether organic components in the soils were responsible for the enhanced activity. Heat treatment of the samples, which deactivates known proteinaceous bacterial and fungal IN (Pouleur et al., 1992), reduced the ice-nucleating activities for all soils. When the dusts were treated with hydrogen peroxide to reduce the organic matter content of the soils, the ice-nucleating activity in three of the four soil dusts examined (soils A, B and C) decreased further (Fig. 6), tending to that expected for the pure mineral.

The ice-nucleating activities of two humic-like substances (HULIS), Leonardite humic acid and SRFA, were also tested in order to examine whether similar substances present in soil organic matter could account for the high temperature IN activity in soils. The resulting activities, expressed as $n_{\mathrm{m}}$, are illustrated in Fig. 7. Shown in the same plot are equivalent data for one of the soil samples (Soil D), which is clearly far more active than either of the two humic substances tested.

\section{Discussion}

In this study we find that at temperatures above about $258 \mathrm{~K}$, the ice-nucleating activities of the fertile soil dusts tested here result from the presence of a thermally labile, carbonaceous component, suggesting that biogenic residues are likely responsible for the observed activities. In contrast, at lower temperatures the ice-nucleating activity of the fertile soils we tested was close to that expected on the basis of the soil mineral components, and could be reconciled with the K-feldspar content of the soil dusts.

The lowest enhancement in ice active site densities, over those estimated from the soil mineralogy, was observed for soil C (Fig. 6), which also had the lowest percentage of organic carbon in the bulk soil ( $2.1 \%$ OC). Conversely, in sample A, which had an OC content typical of an organic $(\mathrm{O})$ soil horizon (12.7\% OC), the ice nucleation activities were not found to be significantly higher than in samples B and D (2.9 and $2.5 \%$ OC). Interestingly, Conen et al. (2011) have reported that $n_{\mathrm{m}}$ increased by roughly 1 order of magnitude for soil dusts in Western Mongolia for each unit increase in the percentage OC (measured in dusts $<15 \mu \mathrm{m}$ ). While in the current study we have examined the relationship between bulk OC and IN activities in the dusts $(<11 \mu \mathrm{m})$, OC content tends to increase with decreasing particle size (Kahle et al., 2002). The implication from this result is that not only the amount of organic carbon, but also its source and composition, play key roles in determining the IN activities of soils.

In all soils examined during the current study a decrease in high temperature ( $T>258 \mathrm{~K}$ ) IN activity was found upon 


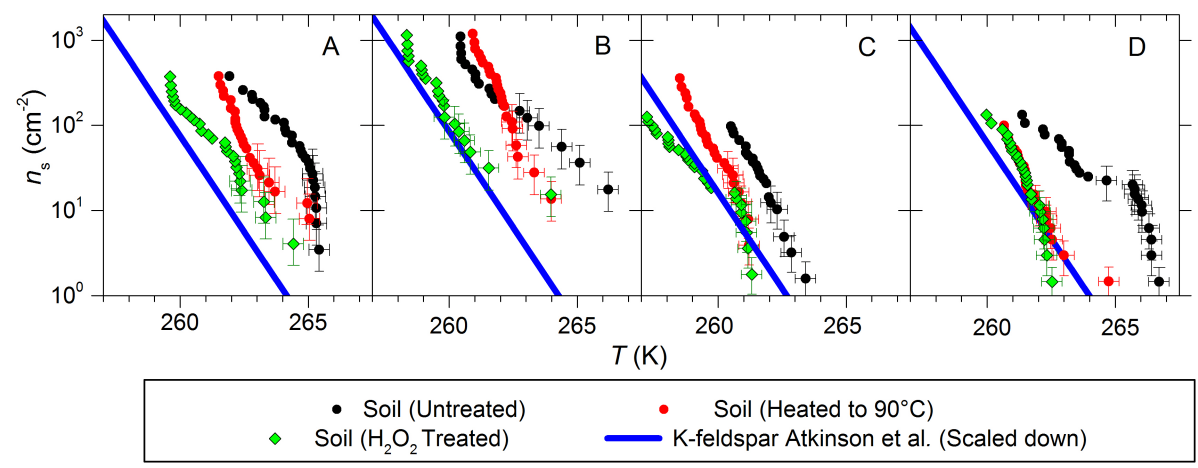

Fig. 6. Ice active site densities $\left(n_{\mathrm{S}}\right)$ determined using microlitre drop freezing experiments for soils A-D $\left(\mathrm{d} T / \mathrm{d} t=-1 \mathrm{~K} \mathrm{~min}{ }^{-1}\right)$. Concentrations used ranged from $0.04-0.1 \mathrm{wt} \%$ between the runs. Shown for comparison is the parameterisation of $n_{\mathrm{S}}$ values for K-feldspar taken from Atkinson et al. (2013), which has been scaled down to the mass fraction of the feldspar in each of the soils as in Fig. 4. For clarity, error bars are only shown for the first 10 data points of each series.

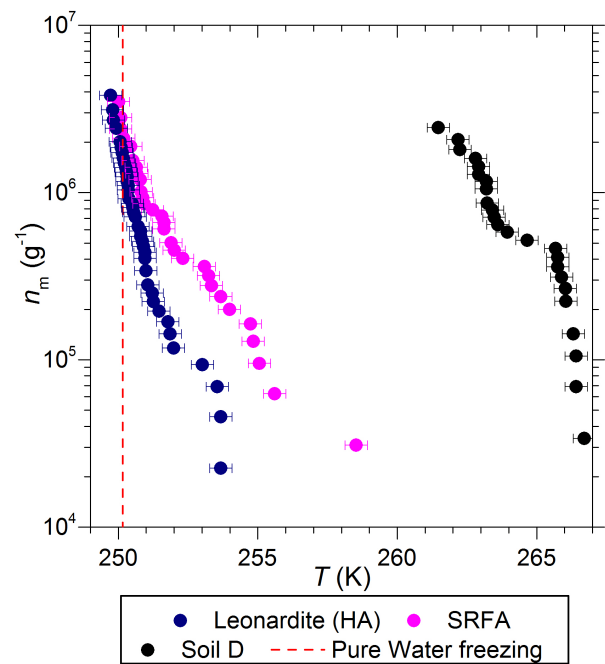

Fig. 7. Ice active site densities per unit mass $\left(n_{\mathrm{m}}\right)$ determined for $0.1 \mathrm{wt} \%$ suspensions of two proxies for humic-like substances (HULIS): leonardite humic acid (HA) and Suwanhee River fulvic acid (SRFA). Also shown are $n_{\mathrm{m}}$ values for a $0.1 \mathrm{wt} \%$ suspension of soil D for comparison. The dashed red line indicates the lower temperature limit for these experiments, above which point less than $10 \%$ of $1 \mu \mathrm{L}$ Milli-Q purified water droplets were observed to freeze across six repeat experiments.

heating (Fig. 6), suggesting that biogenic, likely proteinaceous, species are involved in ice nucleation at these temperatures. Although the activity of proteinaceous IN is decreased by heat treatment, some activity can still be retained. For example, this has been observed after the heat treatment of Snowmax ${ }^{\circledR}$, a lyophilised and irradiated commercial preparation of Pseudomonas syringae (Pummer et al., 2012). Other known non-proteinaceous biogenic ice nuclei, such as those found in pollen, also retain activity after heat treatment at temperatures above $373 \mathrm{~K}$ (Pummer et al., 2012). Upon digestion with the peroxide, the ice active site densities in soils
$\mathrm{A}, \mathrm{B}$ and $\mathrm{C}$ were found to decrease further than when heat treatment was applied. In two of the soil dusts tested (soils A and D) the ice active site densities after treatment with hydrogen peroxide were close to, but generally higher than those estimated on the basis of the soil mineralogy. Although reaction with hydrogen peroxide is a common method employed in the removal of organic matter from soils, no reliable indicator exists showing that complete reaction has occurred and incomplete destruction of soil organic matter is common (Mikutta et al., 2005). Nevertheless, the further lowering of IN activity upon peroxide digestion, towards those expected from the soil mineral composition, provides additional evidence that the activities at low supercoolings stem from the SOM.

While IN associated with live bacteria and fungi are the most well-described biogenic IN in the literature, there is considerable scope for components in SOM other than viable microbes to impact upon the freezing behaviour of immersed soil particles. Indeed, previous estimates of the numbers of live ice-nucleating bacteria in soils have been unable to account for observed ice active site densities (Conen et al., 2011). Non-viable cells, cell membrane fragments and membrane vesicles have all been shown in the laboratory to exhibit IN activity (Maki and Willoughby, 1978; Phelps et al., 1986; Hartmann et al., 2013; Augustin et al., 2013), and dead bacteria have been postulated to contribute significantly to the ice-nucleating ability associated with plant tissues (Ashworth and Kieft, 1995; Lindow, 1983a, b). While the lifetime of IN active proteins derived from bacteria and fungi in soils is unknown, there is evidence to suggest that certain proteins in soils can have extremely long residence times, on the order of centuries (Amelung et al., 2006).

While proteinaceous material from IN active bacteria or fungi could account for the observations here, the diverse composition of SOM makes it difficult to rule out contributions to the high temperature ice-nucleating activities from other organic species present. For instance, soil 
carbohydrates represent a sizeable fraction of SOM, typically comprising $5-25 \%$ of the soil organic matter and can have molecular weights approaching up to $200 \mathrm{kDa}$, which is in the range of known macromolecular IN (Pummer et al., 2012; Stevenson, 1994). Humic substances, such as humic acid, fulvic acid and humin are a dominant component of SOM, accounting for between around $60-80 \%$ of the total soil organic matter in mineral soils (White, 2009). Humiclike substances (HULIS) have been found capable of nucleating ice in both the deposition and contact modes (Fornea et al., 2009; Kanji et al., 2008; Wang and Knopf, 2011) and immersion mode nucleation has also been observed at temperatures below $250 \mathrm{~K}$ (Wang and Knopf, 2011). However, in microlitre drop freezing experiments conducted here on two proxies for natural HULIS (Fig. 7), Leonardite and SRFA, the ice-nucleating activities were found to be far below those observed in soil dusts. This result supports the hypothesis that the high temperature IN activity in soil dusts likely originates from other components in the SOM or the association of SOM with soil mineral dust particles.

On the basis of the results above, we can provide constraints on the potential importance of fertile soil dusts as immersion mode IN in the atmosphere. As discussed in a recent review article by Murray et al. (2012), a first-order approximation of the IN concentration associated with a specific aerosol type can be made on the basis of the ice active site densities together with estimates of the average atmospheric aerosol particulate surface area. We assess the impact of mixed mineral-organic dusts on atmospheric ice nuclei concentrations by estimating that roughly $20 \%$ of the global dust burden emanates from fertile soils. This estimate was chosen based on past studies, indicating that dusts from agricultural areas constitute around $20 \%$ of the total soil dust burden (Ginoux et al., 2012; Tegen et al., 2002; Forster et al., 2007). We then use the range of zonal annual mean particle number densities for the total soil dust aerosol concentration at $600 \mathrm{hPa}$ simulated by Hoose et al. (2010b). The available surface area was then estimated by taking the log average of this range $\left(0.1-50 \mathrm{~cm}^{-3}\right)$, assuming all particles are $1 \mu \mathrm{m}$ in diameter. From this, together with the parameterisation of the soil $n_{\mathrm{S}}$ values presented in Fig. 8, we can estimate the concentration of immersion mode IN between 247 and $267 \mathrm{~K}$ assuming the $20 \%$ of the soil dust burden from fertile soils had the same activity as the soils we sampled. The result is plotted in Fig. 9 (red line) together with measured IN concentrations from between 500-800 hPa (DeMott et al., 2010). For comparison, also shown is the IN number estimated for $100 \%$ of the dust burden (dashed blue line), assuming that $5 \%$ of the dust surface area is K-feldspar. At temperatures greater than about $255 \mathrm{~K}$, the enhanced activities of fertile soils results in ice nuclei concentrations greater than those predicted for the entire dust burden based on feldspar alone. This is consistent with the study of Atkinson et al. (2013), who found that the K-feldspar component of mineral dust

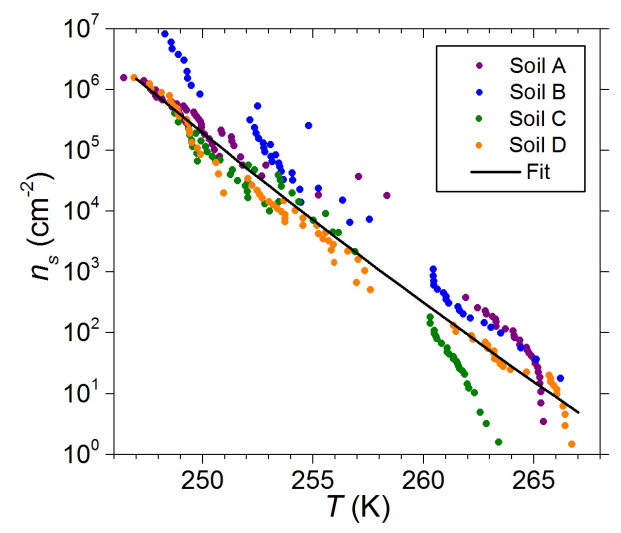

Fig. 8. Fit to ice active site densities for untreated soil dusts as estimated from the micro- and nano- drop freezing experiments. The fit equation used is $\ln n_{\mathrm{s}}=2.974 \times 10^{-3} \times T^{2}-2.160 \times T+366.3$, valid from $246-267 \mathrm{~K}$ and yielding an $R^{2}$ value of 0.941 .

was one of the most important IN below $258 \mathrm{~K}$, but above this temperature other IN types are increasingly important.

A calculation assuming that $100 \%$ of atmospheric dust has the activity of dusts from desert regions as reported by Niemand et al. (2012) is also plotted in Fig. 9 (dark red line). The Niemand et al. (2012) data have a more shallow slope compared with those for feldspar, which results in enhanced nucleation at higher temperatures. This is intriguing since it implies that such dusts may also display enhanced nucleation at warmer temperatures, which may be consistent with Creamean et al. (2013), who found that biological material co-lofted with dusts from arid regions may be important IN. More work clearly needs to be done to assess if organic material in arid region dusts can enhance its ice-nucleating activity.

It should also be noted that the soils investigated during this study are at the lower end of the wide spectrum of icenucleating abilities previously reported for fertile soil dusts. For instance, the most active soil dust examined to date was collected from Western Yakutia (Conen et al., 2011). As an upper limit to the potential number of ice nuclei possible from soil dusts based on current available data, this case is plotted in Fig. 9 (black line) using this enhanced icenucleating ability, with the same assumptions as used for the soils in the current study. This shows that the organic content of soils has the potential to dominate the IN population at temperatures above $258 \mathrm{~K}$.

From the activities of soil dusts measured during this study, the potential contribution to the global IN load is found to be comparable to an upper limit estimate for the contribution of intact bacterial cells (Fig. 9, green line). As indicated by Murray et al. (2012), this upper limit for intact bacteria is likely an overestimate since the most efficient bacteria tested by Lindow et al. (1989) were used in this calculation. Depending on growth conditions and the strains examined, the efficiency of these bacteria to nucleate ice span 


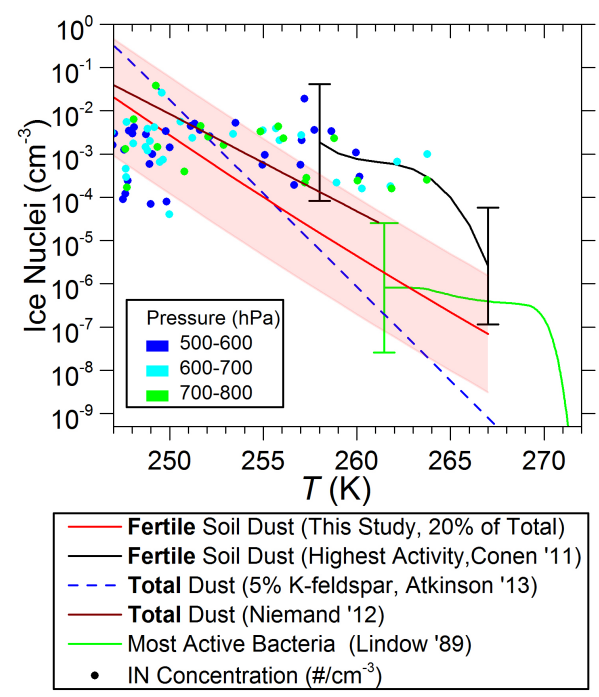

Fig. 9. The concentration of immersion mode IN based on modelled global mean aerosol concentrations and laboratory-derived ice nucleation efficiencies. Calculation of the IN concentrations is detailed in Sect. 4. Aerosol concentrations are taken from Hoose et al. (2010b) at $600 \mathrm{hPa}$, vertical bars represent the range of zonal annual mean particle number concentrations (Hoose et al., 2010b; Murray et al., 2012). For the fertile soil dust IN concentrations (this study and Conen, 2011) it was assumed that the fertile soil dust loading is equivalent to $20 \%$ of the total dust emissions; for the bacteria it was assumed that $1 / 100$ airborne bacteria were as efficient as the most active bacterial ice nuclei from Lindow et al. (1978). IN concentrations for the most active fertile soil dust examined by Conen et al. (2011) are indicated (black line). An estimation of the mineral contribution of IN from desert dusts and fertile soil dusts (i.e. total) is based upon a $5 \% \mathrm{~K}$-feldspar content (dashed blue line). We also show the IN concentration predicted by the Niemand et al. (2012) (dark red line) based on the total dust burden and IN number concentrations measured at a variety of different altitudes from DeMott (2010). Data are colour-coded according to the pressure at which the measurements were performed (see inset).

up to 5 orders of magnitude, hence the contribution of bacteria to the IN population is most likely much smaller than this upper limit. The implication of this result is that nonspecific soil organic matter is more important than bacterial cells (or other whole biogenic particles such as fungal spores or pollen grains) for atmospheric ice nucleation. While it is unclear which components of the organic fraction of soils nucleate ice, fragments from pollen grains, bacteria and fungal spores are all known to retain some of the ice-nucleating ability of their parent particles (Maki et al., 1974; Pouleur et al., 1992; Pummer et al., 2012; Augustin et al., 2013; Hartmann et al., 2013). Hence, estimates of the atmospheric IN loadings determined from biogenic particles based on intact biogenic particles (e.g. bacterial cells, fungal spores and pollen grains) are likely to under-predict the potential importance of biogenic ice nuclei.

\section{Conclusions}

In the current study we have shown that the ice-nucleating activity of fertile soil dusts likely results from the activities of soil organic matter at low supercoolings and mineral components at high supercoolings. Using current estimates of the global atmospheric loadings of particles emitted into the atmosphere resulting from agricultural activities, we have shown that even a relatively low contribution from fertile soil particles to the total dust burden could represent an important source of ice nuclei active at temperatures above $258 \mathrm{~K}$. However, considerable uncertainties remain in constraining the relative importance of mixed mineral-organic dusts as immersion mode ice nuclei in the atmosphere. In particular, although it is clear that substantial amounts of organic material can be found in dust aerosols emitted from fertile soils (e.g. Vega et al., 2001; Aryal et al., 2012; Chow et al., 2003; Rutter et al., 2011), budgets for mineral-dust-associated organic matter emitted into the atmosphere from soils have yet to be established.

The distinctive ice nucleation behaviour of our soil dusts draws interesting parallels with previous suggestions that atmospherically relevant IN, active at temperatures above around $258 \mathrm{~K}$, may be exclusively biogenic (DeMott and Prenni, 2010; Christner et al., 2008a). At similar temperatures, ice nucleation in all of the soil dusts examined during this study was dominated by active sites within the soil organic matter. In slightly supercooled clouds $(265<T<270 \mathrm{~K})$ the Hallet-Mossop ice multiplication process is active, with the result that high temperature IN can have a disproportionate effect on ice production (Hallett and Mossop, 1974). However, both in the atmosphere and in the soil dusts investigated here, biogenic particles active as IN appear to be rare in comparison with inorganic IN, which are capable of nucleating ice at lower temperatures. Consequently at temperatures below $258 \mathrm{~K}$, the population of these rarer biogenic IN is too small to contribute significantly to the total IN concentration. Instead, freezing is driven by the more abundant but less active IN, which in this case are mineral particles.

At mild supercoolings, when ice nucleation by particles derived from fertile soils is likely to be driven by biogenic components, the extent to which environmental stimuli influence the biogenic IN content of soils may represent a key factor in assessing the ice indirect effect of emitted particles. Although the environmental factors modulating the expression of ice-nucleating proteins in bacteria and fungi are highly complex (O'Brien and Lindow, 1988), simple factors such as climate types have been shown to correlate well with the amount of ice nuclei in decaying plant litters (Schnell and Vali, 1976). Given the variability of soil IN efficiencies and their sensitivity to their environment, more work is clearly required before we can quantify the effect of soil dusts on cloud glaciation. 
Acknowledgements. The authors wish to thank V. Phillips for helpful discussions. Financial support for this work was provided by the National Environmental Research Council (NERC) (NE/I013466/1; NE/I020059/1; NE/I019057/1) and the European Research Council (FP7, 240449 ICE). NSU thanks the Nigerian Niger Delta Development Commission (NDDC/DEHSS/2010PGFS/AK/011).

Edited by: J. Curtius

\section{References}

Amelung, W., Zhang, X., and Flach, K.: Amino acids in grassland soils: climatic effects on concentrations and chirality, Geoderma, 130, 207-217, doi:10.1016/j.geoderma.2005.01.017, 2006.

Ansmann, A., Tesche, M., Althausen, D., Müller, D., Seifert, P., Freudenthaler, V., Heese, B., Wiegner, M., Pisani, G., and Knippertz, P.: Influence of Saharan dust on cloud glaciation in southern Morocco during the Saharan Mineral Dust Experiment, J. Geophys. Res.-Atmos., 113, D04210, doi:10.1029/2007jd008785, 2008.

Ansmann, A., Tesche, M., Seifert, P., Althausen, D., Engelmann, R., Fruntke, J., Wandinger, U., Mattis, I., and Müller, D.: Evolution of the ice phase in tropical altocumulus: SAMUM lidar observations over Cape Verde, J. Geophys. Res., 114, D17208, doi:10.1029/2008jd011659, 2009.

Aryal, R., Kandel, D., Acharya, D., Chong, M. N., and Beecham, S.: Unusual Sydney dust storm and its mineralogical and organic characteristics, Environ. Chem, 9, 537-546, doi:10.1071/En12131, 2012.

Ashworth, E. N. and Kieft, T. L.: Principles of Ice Nucleation, in: Biological Ice Nucleation and Its Applications, edited by: Lee Jr., R., Warren, G. J., and Gusta, L. V., American Phytopathological Society, St. Paul, Mn, USA, 1-28, 1995.

Atkinson, J. D., Murray, B. J., Woodhouse, M. T., Carslaw, K., Whale, T. F., Baustian, K., Dobbie, S., O'Sullivan, D., and Malkin, T. L.: Nature, 498, 355-358, doi:10.1038/nature12278, 2013.

Augustin, S., Wex, H., Niedermeier, D., Pummer, B., Grothe, H., Hartmann, S., Tomsche, L., Clauss, T., Voigtländer, J., Ignatius, K., and Stratmann, F.: Immersion freezing of birch pollen washing water, Atmos. Chem. Phys., 13, 10989-11003, doi:10.5194/acp-13-10989-2013, 2013.

Baker, J. B., Southard, R. J., and Mitchell, J. P.: Agricultural Dust Production in Standard and Conservation Tillage Systems in the San Joaquin Valley, J. Environ. Qual., 34, 1260-1269, doi:10.2134/jeq2003.0348, 2005.

Broadley, S. L., Murray, B. J., Herbert, R. J., Atkinson, J. D., Dobbie, S., Malkin, T. L., Condliffe, E., and Neve, L.: Immersion mode heterogeneous ice nucleation by an illite rich powder representative of atmospheric mineral dust, Atmos. Chem. Phys., 12, 287-307, doi:10.5194/acp-12-287-2012, 2012.

Burrows, S. M., Hoose, C., Pöschl, U., and Lawrence, M. G.: Ice nuclei in marine air: biogenic particles or dust?, Atmos. Chem. Phys., 13, 245-267, doi:10.5194/acp-13-245-2013, 2013.

Cantrell, W. and Heymsfield, A.: Production of ice in tropospheric clouds: A review, B. Am. Meteorol. Soc., 86, 795-807, doi:10.1175/Bams-86-6-795, 2005.
Choi, Y.-S., Lindzen, R. S., Ho, C.-H., and Kim, J.: Space observations of cold-cloud phase change, P. Natl. Acad. Sci. USA, 107, 11211-11216, doi:10.1073/pnas.1006241107, 2010.

Chow, J. C., Watson, J. G., Ashbaugh, L. L., and Magliano, K. L.: Similarities and differences in $\mathrm{PM}_{10}$ chemical source profiles for geological dust from the San Joaquin Valley, California, Atmos. Environ., 37, 1317-1340, doi:10.1016/s1352-2310(02)01021-x, 2003.

Christner, B. C., Cai, R., Morris, C. E., McCarter, K. S., Foreman, C. M., Skidmore, M. L., Montross, S. N., and Sands, D. C.: Geographic, seasonal, and precipitation chemistry influence on the abundance and activity of biological ice nucleators in rain and snow, P. Natl. Acad. Sci. USA, 105, 18854, doi:10.1073/pnas.0809816105, 2008a.

Christner, B. C., Morris, C. E., Foreman, C. M., Cai, R., and Sands, D. C.: Ubiquity of biological ice nucleators in snowfall, Science, 319, 1214, doi:10.1126/science.1149757, 2008b.

Conen, F., Morris, C. E., Leifeld, J., Yakutin, M. V., and Alewell, C.: Biological residues define the ice nucleation properties of soil dust, Atmos. Chem. Phys., 11, 9643-9648, doi:10.5194/acp-119643-2011, 2011.

Connolly, P. J., Möhler, O., Field, P. R., Saathoff, H., Burgess, R., Choularton, T., and Gallagher, M.: Studies of heterogeneous freezing by three different desert dust samples, Atmos. Chem. Phys., 9, 2805-2824, doi:10.5194/acp-9-2805-2009, 2009.

Crawford, I., Bower, K. N., Choularton, T. W., Dearden, C., Crosier, J., Westbrook, C., Capes, G., Coe, H., Connolly, P. J., Dorsey, J. R., Gallagher, M. W., Williams, P., Trembath, J., Cui, Z., and Blyth, A.: Ice formation and development in aged, wintertime cumulus over the UK: observations and modelling, Atmos. Chem. Phys., 12, 4963-4985, doi:10.5194/acp-12-4963-2012, 2012.

Creamean, J. M., Suski, K. J., Rosenfeld, D., Cazorla, A., DeMott, P. J., Sullivan, R. C., White, A. B., Ralph, F. M., Minnis, P., Comstock, J. M., Tomlinson, J. M., and Prather, K. A.: Dust and Biological Aerosols from the Sahara and Asia Influence Precipitation in the Western U.S, Science, 339, 1572-1578, doi:10.1126/science.1227279, 2013.

de Boer, G., Morrison, H., Shupe, M., and Hildner, R.: Evidence of liquid dependent ice nucleation in high-latitude stratiform clouds from surface remote sensors, Geophys. Res. Lett., 38, L01803, doi:10.1029/2010GL046016, 2011.

DeMott, P. J.: Quantitative descriptions of ice formation mechanisms of silver iodide-type aerosols, Atmos. Res., 38, 63-99, doi:10.1016/0169-8095(94)00088-U, 1995.

DeMott, P. J. and Prenni, A. J.: New directions: need for defining the numbers and sources of biological aerosols acting as ice nuclei, Atmos. Environ., 44, 1944-1945, doi:10.1016/j.atmosenv.2010.02.032, 2010.

DeMott, P. J., Prenni, A. J., Liu, X., Kreidenweis, S. M., Petters, M. D., Twohy, C. H., Richardson, M., Eidhammer, T., and Rogers, D.: Predicting global atmospheric ice nuclei distributions and their impacts on climate, P. Natl. Acad. Sci. USA, 107, 11217, doi:10.1073/pnas.0910818107, 2010.

DeMott, P. J., Mohler, O., Stetzer, O., Vali, G., Levin, Z., Petters, M. D., Murakami, M., Leisner, T., Bundke, U., Klein, H., Kanji, Z. A., Cotton, R., Jones, H., Benz, S., Brinkmann, M., Rzesanke, D., Saathoff, H., Nicolet, M., Saito, A., Nillius, B., Bingemer, H., Abbatt, J., Ardon, K., Ganor, E., Georgakopoulos, D. G., and Saunders, C.: Resurgence in ice nuclei 
measurement research, B. Am. Meteorol. Soc., 92, 1623-1635, doi:10.1175/2011BAMS3119.1, 2011.

Després, V. R., Huffman, J. A., Burrows, S. M., Hoose, C., Safatov, A. S., Buryak, G., Fröhlich-Nowoisky, J., Elbert, W., Andreae, M. O., and Pöschl, U.: Primary biological aerosol particles in the atmosphere: a review, Tellus B, 64, 349-384, doi:10.3402/tellusb.v64i0.15598, 2012.

Durant, A. J. and Shaw, R. A.: Evaporation freezing by contact nucleation inside-out, Geophys. Res. Lett, 32, L20814, doi:10.1029/2005g1024175, 2005.

Eshel, G., Levy, G., Mingelgrin, U., and Singer, M.: Critical evaluation of the use of laser diffraction for particlesize distribution analysis, Soil Sci. Soc. Am. J., 68, 736-743, doi:10.2136/sssaj2004.7360, 2004.

Field, P., Heymsfield, A., Shipway, B., DeMott, P., Pratt, K., Rogers, D., Stith, J., and Prather, K.: Ice in Clouds Experiment-Layer Clouds. Part II: Testing Characteristics of Heterogeneous Ice Formation in Lee Wave Clouds, J. Atmos. Sci., 69, 1066-1079, doi:10.1175/Jas-D-11-026.1, 2012.

Fornea, A. P., Brooks, S. D., Dooley, J. B., and Saha, A.: Heterogeneous freezing of ice on atmospheric aerosols containing ash, soot, and soil, J. Geophys. Res.-Atmos., 114, D13201, doi:10.1029/2009jd011958, 2009.

Forster, P., Ramaswamy, V., Artaxo, P., Berntsen, T., Betts, R., Fahey, D. W., Haywood, J., Lean, J., Lowe, D. C., and Myhre, G.: Changes in atmospheric constituents and in radiative forcing, in: Climate Change 2007: The Physical Science Basis. Contribution of Working Group I to the Fourth Assessment Report of the Intergovernmental Panel on Climate Change, edited by: Solomon, S., Qin, D., Manning, M., Chen, Z., Marquis, M., Averyt, K. B., Tignor, M., and Miller, H. L., Cambridge University Press, Cambridge, UK, 129-234, 2007.

Garcia, E., Hill, T. C., Prenni, A. J., DeMott, P. J., Franc, G. D., and Kreidenweis, S. M.: Biogenic ice nuclei in boundary layer air over two US High Plains agricultural regions, J. Geophys. Res., 117, D18209, doi:10.1029/2012JD018343, 2012.

Ginoux, P., Prospero, J. M., Gill, T. E., Hsu, N. C., and Zhao, M.: Global-scale attribution of anthropogenic and natural dust sources and their emission rates based on MODIS Deep Blue aerosol products, Rev. Geophys., 50, RG3005, doi:10.1029/2012rg000388, 2012.

Hallar, A. G., Chirokova, G., McCubbin, I., Painter, T. H., Wiedinmyer, C., and Dodson, C.: Atmospheric bioaerosols transported via dust storms in the western United States, Geophys. Res. Lett., 38, L17801, doi:10.1029/2011g1048166, 2011.

Hallett, J. and Mossop, S. C.: Production of secondary ice particles during the riming process, Nature, 249, 26-28, doi:10.1038/249026a0, 1974

Hartmann, S., Augustin, S., Clauss, T., Wex, H., Šantl-Temkiv, T., Voigtländer, J., Niedermeier, D., and Stratmann, F.: Immersion freezing of ice nucleation active protein complexes, Atmos. Chem. Phys., 13, 5751-5766, doi:10.5194/acp-13-57512013, 2013.

Henderson-Begg, S. K., Hill, T., Thyrhaug, R., Khan, M., and Moffett, B. F.: Terrestrial and airborne non-bacterial ice nuclei, Atmos. Sci. Lett., 10, 215-219, doi:10.1002/asl.241, 2009.

Hillier, S.: Use of an air brush to spray dry samples for X-ray powder diffraction, Clay Miner., 34, 127-135, doi:10.1180/000985599545984, 1999.
Hillier, S.: Accurate quantitative analysis of clay and other minerals in sandstones by XRD: comparison of a Rietveld and a reference intensity ratio (RIR) method and the importance of sample preparation, Clay Miner., 35, 291-302, doi:10.1180/000985500546666, 2000.

Holdich, R. G.: Fundamentals of particle technology, Midland Information Technology and Publishing, Shepsted, Leceistershire, UK, 2002.

Hoose, C. and Möhler, O.: Heterogeneous ice nucleation on atmospheric aerosols: a review of results from laboratory experiments, Atmos. Chem. Phys., 12, 9817-9854, doi:10.5194/acp-12-98172012, 2012.

Hoose, C., Kristjánsson, J., and Burrows, S.: How important is biological ice nucleation in clouds on a global scale?, Environ. Res. Lett., 5, 024009, doi:10.1088/1748-9326/5/2/024009, 2010a.

Hoose, C., Kristjánsson, J. E., Chen, J. P., and Hazra, A.: A Classical-Theory-Based Parameterization of Heterogeneous Ice Nucleation by Mineral Dust, Soot, and Biological Particles in a Global Climate Model, J. Atmos. Sci., 67, 2483-2503, doi:10.1175/2010jas3425.1, 2010b.

Jung, S., Tiwari, M. K., and Poulikakos, D.: Frost halos from supercooled water droplets, P. Natl. Acad. Sci. USA, 109, 1607316078, doi:10.1073/pnas.1206121109, 2012.

Kahle, M., Kleber, M., and Jahn, R.: Carbon storage in loess derived surface soils from Central Germany: Influence of mineral phase variables, J. Plant Nutr. Soil Sc., 165, 141-149, doi:10.1002/1522-2624(200204)165:2<141::aidjpln141>3.0.co;2-x, 2002.

Kanji, Z. A., Florea, O., and Abbatt, J. P.: Ice formation via deposition nucleation on mineral dust and organics: dependence of onset relative humidity on total particulate surface area, Environ. Res. Lett., 3, 025004, doi:10.1088/1748-9326/3/2/025004, 2008.

Lindow, S. E.: The role of bacterial ice nucleation in frost injury to plants, Annu. Rev. Phytopathol., 21, 363-384, doi:10.1146/annurev.py.21.090183.002051, 1983a.

Lindow, S. E.: methods of Preventing Frost Injury Caused by Epiphytic Ice-Nucleation-Alctive Bacteria, Plant Dis., 67, 327-333, doi:10.1094/PD-67-327, 1983b.

Lindow, S. E., Arny, D., and Upper, C.: Erwinia herbicola: a bacterial ice nucleus active in increasing frost injury to corn, Phytopathology, 68, 523-527, 1978.

Lindow, S. E., Lahue, E., Govindarajan, A., Panopoulos, N., and Gies, D.: Localization of ice nucleation activity and the iceC gene product in Pseudomonas syringae and Escherichia coli, Mol. Plant Microbe In., 2, 262-272, 1989.

Lohmann, U. and Diehl, K.: Sensitivity Studies of the Importance of Dust Ice Nuclei for the Indirect Aerosol Effect on Stratiform Mixed-Phase Clouds, J. Atmos. Sci., 63, 968-982, doi:10.1175/jas3662.1, 2006.

Maki, L. and Willoughby, K.: Bacteria as biogenic sources of freezing nuclei, J. App. Meteorol., 17, 1049-1053, doi:10.1175/15200450(1978)017<1049:Babsof>2.0.Co;2, 1978.

Maki, L. R., Galyan, E. L., Chang-Chien, M. M., and Caldwell, D. R.: Ice nucleation induced by Pseudomonas syringae, Appl. Environ. Microb., 28, 456-459, 1974.

Mayer, L. M.: Relationships between mineral surfaces and organic carbon concentrations in soils and sediments, Chem. Geol., 114, 347-363, doi:10.1016/0009-2541(94)90063-9, 1994. 
Gee, G. W. and Bauder, J. W.: Particle size analysis, in: Methods of soil analysis. Part 1. Physical and mineralogical methods, edited by: Klute, A., Edn. 2, American Society of Agronomy, Inc., 383411, 1986.

Mikutta, R., Kleber, M., Kaiser, K., and Jahn, R.: Review: Organic Matter Removal from Soils using Hydrogen Peroxide, Sodium Hypochlorite, and Disodium Peroxodisulfate, Soil Sci. Soc. Am. J., 69, 120-135, doi:10.2136/sssaj2005.0120, 2005.

Murray, B. J., Broadley, S. L., Wilson, T. W., Bull, S. J., Wills, R. H., Christenson, H. K., and Murray, E. J.: Kinetics of the homogeneous freezing of water, Phys. Chem. Chem. Phys., 12, 1038010387, doi:10.1039/c003297b, 2010.

Murray, B. J., Broadley, S. L., Wilson, T. W., Atkinson, J. D., and Wills, R. H.: Heterogeneous freezing of water droplets containing kaolinite particles, Atmos. Chem. Phys., 11, 4191-4207, doi:10.5194/acp-11-4191-2011, 2011.

Murray, B. J., O’Sullivan, D., Atkinson, J. D., and Webb, M.: Ice nucleation by particles immersed in supercooled cloud droplets, Chem. Soc. Rev., 41, 6519-6554, doi:10.1039/c2cs35200a, 2012.

Niedermeier, D., Hartmann, S., Shaw, R. A., Covert, D., Mentel, T. F., Schneider, J., Poulain, L., Reitz, P., Spindler, C., Clauss, T., Kiselev, A., Hallbauer, E., Wex, H., Mildenberger, K., and Stratmann, F.: Heterogeneous freezing of droplets with immersed mineral dust particles - measurements and parameterization, Atmos. Chem. Phys., 10, 3601-3614, doi:10.5194/acp-10-36012010, 2010.

Niedermeier, D., Shaw, R. A., Hartmann, S., Wex, H., Clauss, T., Voigtländer, J., and Stratmann, F.: Heterogeneous ice nucleation: exploring the transition from stochastic to singular freezing behavior, Atmos. Chem. Phys., 11, 8767-8775, doi:10.5194/acp11-8767-2011, 2011.

Niemand, M., Möhler, O., Vogel, B., Vogel, H., Hoose, C., Connolly, P., Klein, H., Bingemer, H., DeMott, P., and Skrotzki, J.: A particle-surface-area-based parameterization of immersion freezing on desert dust particles, J. Atmos. Sci., 69, 3077-3092, doi:10.1175/Jas-D-11-0249.1, 2012.

Oades, J.: The role of biology in the formation, stabilization and degradation of soil structure, Geoderma, 56, 377-400, doi:10.1016/0016-7061(93)90123-3, 1993.

O'Brien, R. D. and Lindow, S. E.: Effect of plant species and environmental conditions on ice nucleation activity of Pseudomonas syringae on leaves, Appl. Environ. Microb., 54, 2281-2286, 1988.

Oorts, K., Vanlauwe, B., Recous, S., and Merckx, R.: Redistribution of particulate organic matter during ultrasonic dispersion of highly weathered soils, Eur. J. Soil Sci., 56, 77-91, doi:10.1111/j.1351-0754.2004.00654.x, 2005.

Özer, M., Orhan, M., and Işik, N. S.: Effect of Particle Optical Properties on Size Distribution of Soils Obtained by Laser Diffraction, Environ. Eng. Geosci., 16, 163-173, doi:10.2113/gseegeosci.16.2.163, 2010.

Pansu, M. and Gautheyrou, J.: Handbook of Soil Analysis: Mineralogical, Organic and Inorganic Methods, Springer, Berlin, 2006.

Phelps, P., Giddings, T. H., Prochoda, M., and Fall, R.: Release of cell-free ice nuclei by Erwinia herbicola, J. Bacteriol., 167, 496502, 1986.

Philips, V. T. J., Donner, L. J., and Garner, S. T.: Nucleation processes in deep convection simulated by a cloud-system-resolving model with double-moment bulk microphysics, J. Atmos. Sci., 64, 738-761, doi:10.1175/JAS3869.1, 2007.

Phillips, V. T. J., Andronache, C., Christner, B., Morris, C. E., Sands, D. C., Bansemer, A., Lauer, A., McNaughton, C., and Seman, C.: Potential impacts from biological aerosols on ensembles of continental clouds simulated numerically, Biogeosciences, 6 , 987-1014, doi:10.5194/bg-6-987-2009, 2009.

Pieri, L., Bittelli, M., and Pisa, P. R.: Laser diffraction, transmission electron microscopy and image analysis to evaluate a bimodal Gaussian model for particle size distribution in soils, Geoderma, 135, 118-132, doi:10.1016/j.geoderma.2005.11.009, 2006.

Pouleur, S., Richard, C., Martin, J. G., and Antoun, H.: Ice nucleation activity in Fusarium acuminatum and Fusarium avenaceum, Appl. Environ. Microb., 58, 2960-2964, 1992.

Pratt, K. A., DeMott, P. J., French, J. R., Wang, Z., Westphal, D. L., Heymsfield, A. J., Twohy, C. H., Prenni, A. J., and Prather, K. A.: In situ detection of biological particles in cloud ice-crystals, Nat. Geosci., 2, 398-401, doi:10.1038/Ngeo521, 2009.

Prenni, A. J., Petters, M. D., Kreidenweis, S. M., Heald, C. L., Martin, S. T., Artaxo, P., Garland, R. M., Wollny, A. G., and Pöschl, U.: Relative roles of biogenic emissions and Saharan dust as ice nuclei in the Amazon basin, Nat. Geosci., 2, 402-405, doi:10.1038/Ngeo517, 2009.

Prospero, J. M., Ginoux, P., Torres, O., Nicholson, S. E., and Gill, T. E.: Environmental characterization of global sources of atmospheric soil dust identified with the Nimbus 7 Total Ozone Mapping Spectrometer (TOMS) absorbing aerosol product, Rev. Geophys., 40, 1002, doi:10.1029/2000rg000095, 2002.

Pruppacher, H. R. and Klett, J. D.: Microphysics of Clouds and Precipitation, Kluwer Academic Publishers, New York, 1997.

Pummer, B. G., Bauer, H., Bernardi, J., Bleicher, S., and Grothe, H.: Suspendable macromolecules are responsible for ice nucleation activity of birch and conifer pollen, Atmos. Chem. Phys., 12, 2541-2550, doi:10.5194/acp-12-2541-2012, 2012.

Riechers, B., Wittbracht, F., Hütten, A., and Koop, T.: The homogeneous ice nucleation rate of water droplets produced in a microfluidic device and the role of temperature uncertainty, Phys. Chem. Chem. Phys., 15, 5873-5887, doi:10.1039/C3CP42437E, 2013.

Rutter, A. P., Snyder, D. C., Schauer, J. J., Sheesley, R. J., Olson, M. R., and DeMinter, J.: Contributions of resuspended soil and road dust to organic carbon in fine particulate matter in the Midwestern US, Atmos. Environ., 45, 514-518, doi:10.1016/j.atmosenv.2010.10.014, 2011.

Sassen, K., DeMott, P. J., Prospero, J. M., and Poellot, M. R.: Saharan dust storms and indirect aerosol effects on clouds: CRYSTAL-FACE results, Geophys. Res. Lett., 30, 1633, doi:10.1029/2003gl017371, 2003.

Schnell, R. and Vali, G.: Atmospheric ice nuclei from decomposing vegetation, Nature, 236, 163-165, doi:10.1038/236163a0, 1972.

Schnell, R. and Vali, G.: Biogenic ice nuclei: Part I. Terrestrial and marine sources, J. Atmos. Sci., 33, 1554-1564, 1976.

Simoneit, B. R. T., Elias, V. O., Kobayashi, M., Kawamura, K., Rushdi, A. I., Medeiros, P. M., Rogge, W. F., and Didyk, B. M.: Sugars dominant water-soluble organic compounds in soils and characterization as tracers in atmospheric particulate matter, Environ. Sci. Technol., 38, 5939-5949, doi:10.1021/Es0403099, 2004. 
Skjemstad, J. and Baldock, J.: Total and Organic Carbon, in: Soil Sampling and Methods of Analysis, 2nd Edn., CRC Press, 2007.

Sperazza, M., Moore, J. N., and Hendrix, M. S.: High-resolution particle size analysis of naturally occurring very fine-grained sediment through laser diffractometry, J. Sediment. Res., 74, 736-743, doi:10.1306/031104740736, 2004.

Stevenson, F. J.: Humus chemistry: Genesis, composition, reactions, Wiley, New York, NY, 1994.

Storey, R. A. and Ymen, I.: Solid State Characterization of Pharmaceuticals, John Wiley \& Sons, Sussex, UK, 2011.

Tegen, I., Harrison, S. P., Kohfeld, K., Prentice, I. C., Coe, M., and Heimann, M.: Impact of vegetation and preferential source areas on global dust aerosol: Results from a model study, J. Geophys. Res., 107, 4576, doi:10.1029/2001jd000963, 2002.

Tegen, I., Werner, M., Harrison, S. P., and Kohfeld, K. E.: Relative importance of climate and land use in determining present and future global soil dust emission, Geophys. Res. Lett., 31, L05105, doi:10.1029/2003g1019216, 2004.

Twohy, C. H., DeMott, P. J., Pratt, K. A., Subramanian, R., Kok, G. L., Murphy, S. M., Lersch, T., Heymsfield, A. J., Wang, Z., and Prather, K. A.: Relationships of biomass-burning aerosols to ice in orographic wave clouds, J. Atmos. Sci., 67, 2437-2450, doi:10.1175/2010jas3310.1, 2010.

Vali, G.: Stormy Weather Group Report, McGill University, Montreal, 1968.

Vali, G.: Quantitative Evaluation of Experimental Results an the Heterogeneous Freezing Nucleation of Supercooled Liquids, J. Atmos. Sci., 28, 402-409, doi:10.1175/15200469(1971)028<0402:QEOERA>2.0.CO;2, 1971.

Vali, G.: Nucleation terminology, J. Aerosol Sci., 16, 575-576, 1985.

Vali, G.: Principles of Ice Nucleation, in: Biological Ice Nucleation and Its Applications, edited by: Lee Jr., R., Warren, G. J., and Gusta, L. V., American Phytopathological Society, St. Paul, Mn, USA, 1-28, 1995.
Vali, G.: Repeatability and randomness in heterogeneous freezing nucleation, Atmos. Chem. Phys., 8, 5017-5031, doi:10.5194/acp-8-5017-2008, 2008.

Vega, E., Mugica, V., Reyes, E., Sánchez, G., Chow, J. C., and Watson, J. G.: Chemical composition of fugitive dust emitters in Mexico City, Atmos. Environ., 35, 4033-4039, doi:10.1016/s1352-2310(01)00164-9, 2001.

Wang, B. and Knopf, D. A.: Heterogeneous ice nucleation on particles composed of humic-like substances impacted by $\mathrm{O}_{3}$, J. Geophys. Res.-Atmos., 116, D03205, doi:10.1029/2010jd014964, 2011.

Welti, A., Lüönd, F., Kanji, Z. A., Stetzer, O., and Lohmann, U.: Time dependence of immersion freezing: an experimental study on size selected kaolinite particles, Atmos. Chem. Phys., 12, 9893-9907, doi:10.5194/acp-12-9893-2012, 2012.

Westbrook, C. and Illingworth, A.: Evidence that ice forms primarily in supercooled liquid clouds at temperatures $>-27^{\circ} \mathrm{C}$, Geophys. Res. Lett., 38, L14808, doi:10.1029/2011GL048021, 2011.

Westbrook, C. and Illingworth, A.: The formation of ice in a longlived supercooled layer cloud, Q. J. Roy. Meteor. Soc, 139, 2209 2221, doi:10.1002/qj.2096, 2013.

White, R. E.: Principles and practice of soil science: the soil as a natural resource, Wiley-Blackwell, Oxford, UK, 2009.

Yang, W. C.: Handbook of fluidization and fluid-particle systems, CRC Press, 2003.

Yano, J.-I. and Phillips, V.: Ice-Ice Collisions: An Ice Multiplication Process in Atmospheric Clouds, J. Atmos. Sci., 68, 322-333, doi:10.1175/2010jas3607.1, 2011.

Zender, C. S., Miller, R. L. R. L., and Tegen, I.: Quantifying mineral dust mass budgets:Terminology, constraints, and current estimates, Eos, Trans. Am. Geophys. Union, 85, 509-512, doi:10.1029/2004eo480002, 2004. 